\title{
EVALUATION ON LANGUAGE ATTITUDE OF PRESIDENTIAL CANDIDATES IN THE DISCOURSE OF DEBAT CAPRES 2019: APPRAISAL ANALYSIS
}

\author{
Dian Marisha Putri \\ Faculty of Cultural Science, \\ Universitas Sumatera Utara, Medan, Indonesia \\ E-mail: dian.marisha@usu.ac.id
}

Received: 17 September 2019

Accepted: 14 January 2020

\begin{abstract}
General Election in 2019 is considered as the biggest party in democracy; it was used as the source of data from the third and the fourth segment on March 30, 2019. They were then transcribed and analyzed by using appraisal pattern study based on three analyses: engagement, attitude, and graduation in the appraisal pattern attitude. The result of the research in DC discourse consisted of engagement, attitude, and graduation. The attitude pattern of the presidential candidates comes from personality and the 'order' of political parties. Negative attitude is conveyed in the forms of expressions in dissatisfaction, injustice, greed, ambition, moral messages, noble values, and generosity. The function of presidential candidate debate is in the series of democratic system. Positive attitude identified in the Presidential Debate discourse through the utterances of Presidential Candidate 1 and Presidential Candidate 2 was analyzed through their implicit and explicit expressions such as a) acting in the firm way, b) acting hesitatingly, c) patience, and optimistic, and d) attitude toward gender.
\end{abstract}

Keywords: Appraisal. Presidential Candidate Debate, Attitude

\section{Introduction}

The 2019 General Election is the biggest democratic event by combining Pilpres (Presidential Election) of 2019 in a series of elections which agenda is presidential election. The data of Presidential Candidate (henceforth, DC) debate of 2019 were analyzed by using appraisal pattern which was obtained from DC segment-4 on March 30, 2019. The discourse of DC was transcribed in the written form and analyzed by using appraisal analysis consisted of three types of analysis - engagement, attitude, and graduation.

Appraisal analysis is concerned with the language of evaluation, attitude, and emotion. The meaning used by the speakers or in the text is to distinguish the level of their engagement in own language. There are three types of Appraisal system - engagement, attitude, and graduation.

Appraisal study analyzes attitude correlated with social interaction and is focused on attitude and values negotiated with readers as what Martin points out that "Appraisal is concerned with evaluation: the kinds of attitudes that are negotiated in a text, the strength of the feeling involved and the ways in which values are sourced and readers aligned (Martin, 2003:22)." 
Appraisal analysis is focused on the evaluation on attitude in a text. It is the combination of the power of feeling found in a text with the way how to get the values and its readers (Martin, 2003: 16). Appraisal study analyzes attitude related to social interaction. The focus in attitude and values is negotiated with the readers.

Attitude is related to evaluation on object, people's character, and feeling. It consists of 3 basic evaluations - affect (one's feeling), judgment (one's character), and appreciation (value of an object).

Affect can be expressed through verbs which are related to the process of emotion (mental processes) such as to love, to hate, to frighten / to reassure, to interest / to bore, to enrage / to placate. It can be expressed through adverbs (adverbs of manner) such as happily / sadly and through adjectives which are related to emotion (adjectives of emotion) such as happy / sad, worried / confident, angry / pleased, keen / uninterested.

The system of attitude related to three semantic areas is emotion, aesthetics, and ethics. Evaluation system includes evaluation on behavior; for example, self-esteem (positive: to admire, negative: to criticize), or social sanction (positive: to praise, negative: to condemn). In consequence, evaluation on self-esteem is related to a lower or a higher status of a person evaluated by the other people (White, 2001).

Graduation/Amplifying attitude is how an attitude is applied. One thing which should be heeded about attitude is its gradable nature. Amplifying attitude has two types: force which is related to the fluctuation of voice and to intensifiers (word strength), attitudinal lexis (a word which has attitude), metaphor, and swearing. Martin and Rose (2003) point out that evaluation system is a framework which is aimed to map attitudes in a text, the structure of lexico-grammatical terms, and grammatical sources used by writers to position them among the participants and various events.

\section{Research Methodology}

Descriptive qualitative approach is a clear writing style of a research which makes a reader be able to know the substance of DC. The discourse of DC 2019 as primary and secondary data was obtained from literature. An analysis of qualitative data, according to Bodgan and Bikle in Moleong (2005: 248) is an attempt to work with data, to organize them, to sort them to be a unit which can be managed, to synthesize them, to seek, to find the important ones and what should be learned, and to decide what can be told to someone else. McDrury in Moleong (2005: 248) mentions the stages of analyzing qualitative data as follows: a) reading and studying the data and transcribing the discourse of the debate, $b$ ) identifying the keywords and ideas in the discourse of the debate, c) studying the keywords, d) writing the model, e) coding all which have been done, and f) concluding the result of the analysis of the discourse.

\section{Results and Discussion}

\subsection{Attitude of Presidential Candidates}

The appraisal analysis of the vocabulary on the data in the discourse of DC 2019 dialogues was based on the three types of analysis - engagement, attitude, and graduation. Ideology in the DC 2019 discourse was latent and the analysis on appraisal discourse was to evaluate and interpret the realization of the ideology. The result of the analysis on the data of DC 2019 was to identify its ideology. The DC discourse was analyzed as the expression of the feeling of the presidential candidate (henceforth, candidate) toward the phenomena conveyed in the DC as the candidates' attitude expressed implicitly and explicitly such as a) 
acting in a firm way, b) acting hesitatingly, c) patience, d) optimism, and e) attitude toward gender. All of them will be discussed in detail.

\subsubsection{Acting in a Firm Way}

A leader's firm behavior can be seen from his positive attitude, either explicitly or implicitly, identified by a feeling in responding to various things as the perspective of idealism which has been developed by the candidates, refracted through their characteristics. The firm attitude of candidate 2 as positive idealism in criticizing social reality or an attempt to get defensive when he is criticized (apologies).

This is seen from the clauses of firmness expressed in optative desiderative clauses or expectation clauses strengthened by lexis "will" as follows: 1) "...therefore, I will upgrade all law enforcement officials, I will instruct...", 2) "I will confirm that there will be no discrimination on any tribes, any religion, any ethnicities. The essence is that they have the responsibility for the executive." 3) "Thus, I guarantee that if any government officials violate the law, I will fire them, keep my words, ladies and gentlemen." 4) Probowo-Sandi team: "We will uphold HAM, and it is a must. All of us will be proper."

The candidate 1 said, "If there is persecution, as what Pak Sandi accuses, it is easy, let me know and I will punish the perpetrator.'

\subsubsection{Acting Hesitatingly}

Organizing emotion is the form of patience which can affect the balance and the stability of emotion as what has been expected by everyone. However, hesitation as an emotive attitude of distrust against one of the candidates is the result of distrust against his leadership as a political opponent. Distrust attitude as the form of hesitation will yield failure in leading Indonesia in 5 years ahead.

The candidate 2 used lexis "maybe" four times in clauses: 1) I think maybe we are the majority in all parties." 2) Sir, we maybe reach 40 percent or maybe not reach 40 percent. I have to say (that) maybe Pak Jokowi's team does not work efficiently."

Candidate 2 also used the lexis "must" 14 times while candidate 1 mentioned it 4 times. The clauses are "I must say that it is most possibly that Pak Jokowi's team does not work efficiently." "Infrastructure must be provided for the people, not the people for infrastructure, we must calculate economy." The attitude of distrust as the form of hesitation will yield failure in leading Indonesia in 5 years ahead.

\subsubsection{Optimistic Attitude}

The candidates who have the insight for the future have to have optimistic attitude in looking on various complicated problems of the State. Optimistic attitude is an attitude which is reflected in the self-confidence of the candidates in considering the power of natural resources and human resources. In this case they used "can" in 26 lexies and "have to" in 8 lexies. This was reflected in the DC 2019 with the clauses as follows: "The prerequisite is that foreign workers who work in Indonesia have to speak Indonesian fluently or at least they can speak English.

The use of lexis, "can" was found in 26 frequencies of clause. One of the examples used by candidate 2 in the clause, "We can count numbers but we talk about output, we can have more. So, what we are waiting for is what we cannot do right now." 
Candidate 1 also used the lexis "can" in 8 clauses; for example, "Our country can protect its people." "Law has to be able to (= can) provide certainty." Law can provide peace and comfort to all Indonesian people."

Optimistic attitude is also identified by the use of lexis "must" which was mentioned 12 lexies by candidate 2 and 4 lexies by candidate 1 . Candidate 2 said, "Law must be enforced for little people." "We must provide welfare for them." "HAM must be present in Indonesia." "Infrastructure must be for the people." "We must preserve cost and infrastructure must be oriented to the interest of all people." Candidate 1 said, "The position must be given to professionals and not only to the persons from political parties." "Why we must differentiate which party is." "Philanthropy must be given to them."

\subsubsection{Negative Attitude}

Negative attitude toward government institutions or toward individuals always exists due to dissatisfaction with the reality or discrepancy. Based on the analysis on the perception of the candidates in the form of affect was identified that in the DC discourse, one of the candidates expressed the contradicted attitude toward the government, the negative attitude of candidate 1 was as follows: "But I see that in the management structure of the political parties, strategic positions such as General Chairperson, Head of Board of Patrons, Head of Board of Advisors, Head of Executive Committee, Vice Head of Executive Committee, General Secretary, and Treasurer; all of them are men. Can you explain this inconsistency?" "Actually, I don't need to answer it since Pak Prabowo admits it." Based on the analysis on the data about the perception of the candidates in the form of affect, it was identified that the candidates in the DC discourse text often expressed negative attitude toward his opponent with the perspective of management structure of the political parties. This clause is a cynical remark to the authorities as the realization of self-expression toward candidate 2.

Negative attitude was also expressed by candidate 2 to candidate 1 in the lexis "must" as in "I also must say that it is most possible that Pak Jokowi's team does not work efficiently." "Infrastructure must be for the people, not the people for infrastructure. Infrastructure must be oriented to the interest of all people." "We must think clearly in seeing that infrastructure must increase our economic power. I also must say about the possibility that Pak Jokowi's team does not work efficiently."

The analysis on the data about the perspective of candidate 2 as the affect of negative attitude toward candidate 1 showed in the clause, "Pak Jokowi's work does not work efficiently, infrastructure must be for the people; it is strengthened by the clause, "It is mostly possible (that) Pak Jokowi's team does not work efficiently as a cynical remark toward the authorities as the realization of self-expression of candidate 2 .

\subsubsection{Attitude toward Gender}

Human ambition can mean the attitude of coercion adhered to man. Ambition is surely related to loose and contradicted dichotomy since it is a strong desire to reach what is wanted, either properly or improperly. Excessive ambition is called ambitious which is the end justifies the means which should be avoided.

Prabowo Subianto: "OK, I think that's it, but today the people evaluate what you have praised for, but it, of course, causes a great loss for the country and the people. We don't need to talk about individuals, and we are proud of women's good position, but they have to be skillful and pro-people; they should not make policies which harm people. This is the problem! 
Thus, I will never be proud of their position because they are women. They are women but they do not take side to people, what should be proud of?"

Lexis which has negative attitude toward gender conveyed by candidate 1 and candidate 2 indicated the injustice toward women. But later it is denied by Prabowo with the clause, "We don't need to talk about individuals, and we are proud of women's good position. We need women, but they have to be skillful and pro-people." Critical attitude of candidate 1 toward gender had been denied by candidate 2 about inappropriate facts.

The expression of dissatisfaction realized through the attitude of injustice, greed, and ambition as the form of social reality can be analyzed in the following clauses: heteroglossia: inter-vocation: open. In the analysis on sub-heteroglossia in the sub-analysis of inter-vocation is divided into interpolation and assimilation. In the post-analysis of the data on engagement: sub-heteroglossia: inter-vocation: open, they were divided into modality, sensory, and rumors which were identified through the data of DC 2019 discourse.

The response of candidate 2, "OK, I think that's it, but today the people evaluate what you have praised for, but it, of course, causes a great loss for the country and the people." This clause was strengthened by the clause, "But I think we don't need to talk about individuals, and we are proud of women's position, but they have to be skillful and pro-people; they should not make policies which harm people, that is the problem. So, I will not be proud because they are women; they are women and they do not take sides to their own people, I think we don't need to be proud of them."

Paradoxical lexis was found in clauses, 1) "You've just said you were proud of" versus "it indicates a great loss." 2) "We're proud of women's good position" versus "they have to be skillful and pro-people." 3) they are women and they do not take sides to their own people," versus "I think we don't need to be proud of them." Positive appreciation in the lexis "credible", positive appreciation clause attached to negative appreciation clause will yield negative clause.

\section{Conclusion}

The result of the analysis on DC 2019 discourse in the candidates' perception in the form of affect shows that hesitating attitude constitutes emotive attitude toward distrust in his political opponent's leadership as it is seen in 1) The attitude of distrust as the form of hesitation will yield failure in leading Indonesia in 5 years ahead, as it was used by candidate 2 in the lexis, "maybe," 2) optimistic attitude is an attitude reflected in candidate's selfconfidence by using the lexis of "can" and "must," 3) candidate's negative attitude toward government's institutions or toward personality always appeared due to dissatisfaction with the reality and discrepancy, 4) optimistic attitude is reflected in candidate's self-confidence in searching for opportunity by using the lexis of "can" and the lexis of "must, and 5) negative attitude toward gender which has conveyed by candidate 1 reflects the injustice toward women.

The expression of dissatisfaction realized through the attitude toward injustice, greed, and ambition as the reflection of social reality can be analyzed in the following clause: heteroglossia: inter-vocation: Open in the analysis on sub-heteroglossia in the sub-analysis of inter-vocation by using paradoxical lexis.

\section{References}

Berg, Bruce L. (1989). Qualitative Research Methods. Boston: Allyn and Bacon. 
Bungin, B. (2007). Penelitian Kualitatif: Komunikasi, Ekonomi, Kebijakan Publik, dan Ilmu Sosial Lainnya. Jakarta: Kencana.

Eriyanto. (2001). Analisis Wacana. Malang: LkiS.

Egginz, Suzanne. (1994). An Introduction to Systemic Functional Linguistics. London: Pinter Publisher

Fairlough, Norman. (2003). Language and Power: Relasi Bahasa, Kekuasaan dan Ideologi. THE MESSENGER, Volume III, Nomor 1, Edisi Juli 201135

Halliday, M. A. K. (1994). Introduction to Functional Grammar. London: Arnold.

Martin, J. R. (1992). ENGLISH TEXT System and Structure. Amsterdam: John Benjamins Publishing Company.

Martin, J. R and Rose, David. (2003). Working with Discourse: Meaning Beyond the Clause. London: Continuum.

Miles, M. B and Huberman, A. M. (1992). Analisis Data Kualitatif. Translation

Tjetjep Rohendi Rohidi. Jakarta: UI PRESS

Moleong, Lexy J. (2007). Metodologi Penelitian Kualitatif, Revised Ed. Bandung: Remaja Rosda Karya.

Ratna, Nyoman Kutha. (2006). Metode Penelitian Kajian Budaya dan Ilmu Sosial Humaniora Pada Umumnya. Yogyakarta: Pustaka Pelajar

Sinar, Tengku Silvana. (2010). "Upaya penelitian dalam Merawat Kearifan Lokal." Harian Analisa Medan 7 Februari 2010.

Sunarto. (1991). Debat Capres Purwa Gaya Yogyakarta, Sebuah Tinjauan tentang Bentuk, Ukiran, Sunggingan, Jakarta: Balai Pustaka.

Spradley, James P. (1980). Doing Participants Observation. Participants' Observation. New York: Holt Rinehart and Winston. 